\title{
Principles of Ecological Riverfront Design Redefined
}

\author{
NABILAH REDZUAN ${ }^{1 *}$ AND NURUL SYALA ABDUL LATIP ${ }^{2}$ \\ ${ }^{1}$ Research Assistant, Department of Architecture, International Islamic \\ University Malaysia. \\ ${ }^{2}$ Assistant Professor, Department of Architecture, International Islamic \\ University Malaysia
}

\section{Email: nabilahredzuan312@gmail.com}

December 11, 2015I Revised: January 14, 2016 I Accepted: January 22, 2016

Published online: July 04, 2016

The Author(s) 2016. This article is published with open access at www.chitkara. edu.in/publications

\begin{abstract}
Channelization of rivers, along with beautification and structured designated landscape design along the riverbanks, are parts of the development that occur in the urban centres around the world. Such developments are often taken up to prevent natural catastrophes such as floods, without considering the nature of the river itself. Realizing this mistake and its adverse effects towards the environment, many developed countries, such as the U.S.A., U.K., Japan, China and, many more, have started to ecologically reorganize riverfront designs to ensure that rivers are restored to their natural condition. Various principles of ecological riverfront design are available, but the information is patchy and in different documents. Hence, this research aimed at redefining the principles of ecological riverfront design. A qualitative method, using comprehensive content analysis of journals and reports on ecological riverfront designs and ecological riverfront design guidelines from selected countries, was employed to redefine such principles. In summary, these principles could become a reference for architects, planners, engineers and other related professional bodies to reconsider the ecological aspect of riverfronts while planning and creating the urban spaces along the riverbanks, thereby indirectly promoting urban sustainability within the urban cities.
\end{abstract}

Keywords: Riverfront Design, Principles of Ecological Riverfront Design, Riverbank, Sustainability, River

\section{INTRODUCTION}

Creative Space (CS)

Vol-4, No-1

July 2016

A River is one of the valuable natural resources, especially for human life and its environment. The evolution of rivers since the beginning of civilisation have shown their importance in shaping and influencing the development of 
Redzuan, $\mathrm{N}$ Abdul Latip, NS human settlements, which in turn have led to the development of large cities around the world [14]. Malaysia is also not excluded from this phenomena as the settlements originally started and spread up along the riverbanks [12]. Many urban centres in Malaysia, such as Kuala Lumpur, Melaka, Kuching and Terengganu, were established after the settlements had developed on riverbanks or in river valleys. Therefore, understanding the historical phases of riverfront development is important because of its influence on development of urban centres [23]. The 'riverfront' stated here represents the water edge area, where the city meets the river (Fig. 1).

Referring to the Fig. 2, the riverfront is part of the waterfront development. Thus, the history of riverfront development can be referred to as the waterfront development. Timur (2013) cited that the historical evolution of waterfront can be seen as divided into four phases, starting with the emergence of waterfront cities as Phase 1, the growth of waterfronts as Phase 2, the decline of waterfronts as Phase 3 and, the rediscovery of waterfronts as Phase 4 [23] (Fig. 3).

Trading and transportation activities were the main catalysts that stimulated the growth of waterfronts as the big cities and settlements started to expand during the second phase. However, the rapid developments that occurred all around the world caused the deterioration of the waterfront. During this time, as non-water industries had monopolized the scene, the waterfront was rendered inaccessible and later became dead. As a matter of fact, shifting from the natural to the urban environment lead the river ecosystem to gradually lose its function and natural characteristics. Impacts such as reduction of sediment loads, changing of the river channel and its flow, invasion of non-native plants in watershed areas and introduction of flood hazards [29] due to human activities such as channelization, dam construction, diversion and culverting, all led to negative consequences, causing major ecological damage on the ecosystem. According to Md. Yassin et al (2010), the abandonment of waterfront for many years also contributes to the lack of water sensitivity in the urban ecosystem. The historical evolution of the waterfront also distinguishes it into five categories, according to its location vis-à-vis the water (as cited in [23]:

Realizing the natural and commercial failure, a research into the recovery of waterfronts was conducted to regenerate them for public use. This is the phase that is currently being developed all around the world. The rediscovery of the waterfront, i.e., the Phase 4 , was conducted through three phases. The first phase of development focused on the flood control. In the second phase, the waterfront development had focused on the transformation of riverbanks area into parks and recreation areas. Some actions have also been taken to overcome the stated problems but much is still lacking, and several issues are not yet properly resolved. Processes, such as river channelization, are conducted 


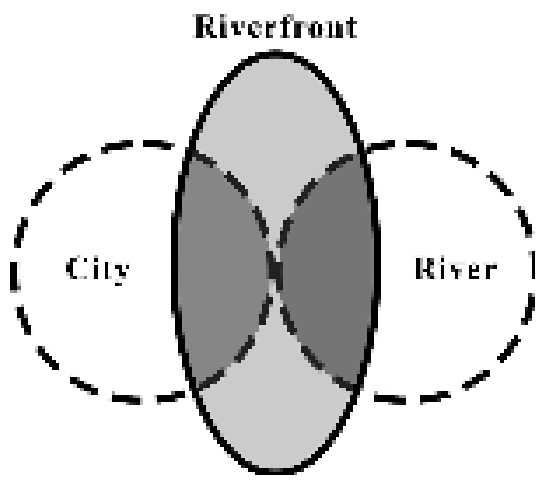

Figure 1: Conceptual Diagram for understanding the Riverfront area
Principles of

Ecological

Riverfront Design

Redefined

Figure 2: Categories of Urban Waterfronts according to its location with water (Source: as cited in Timur, 2013).
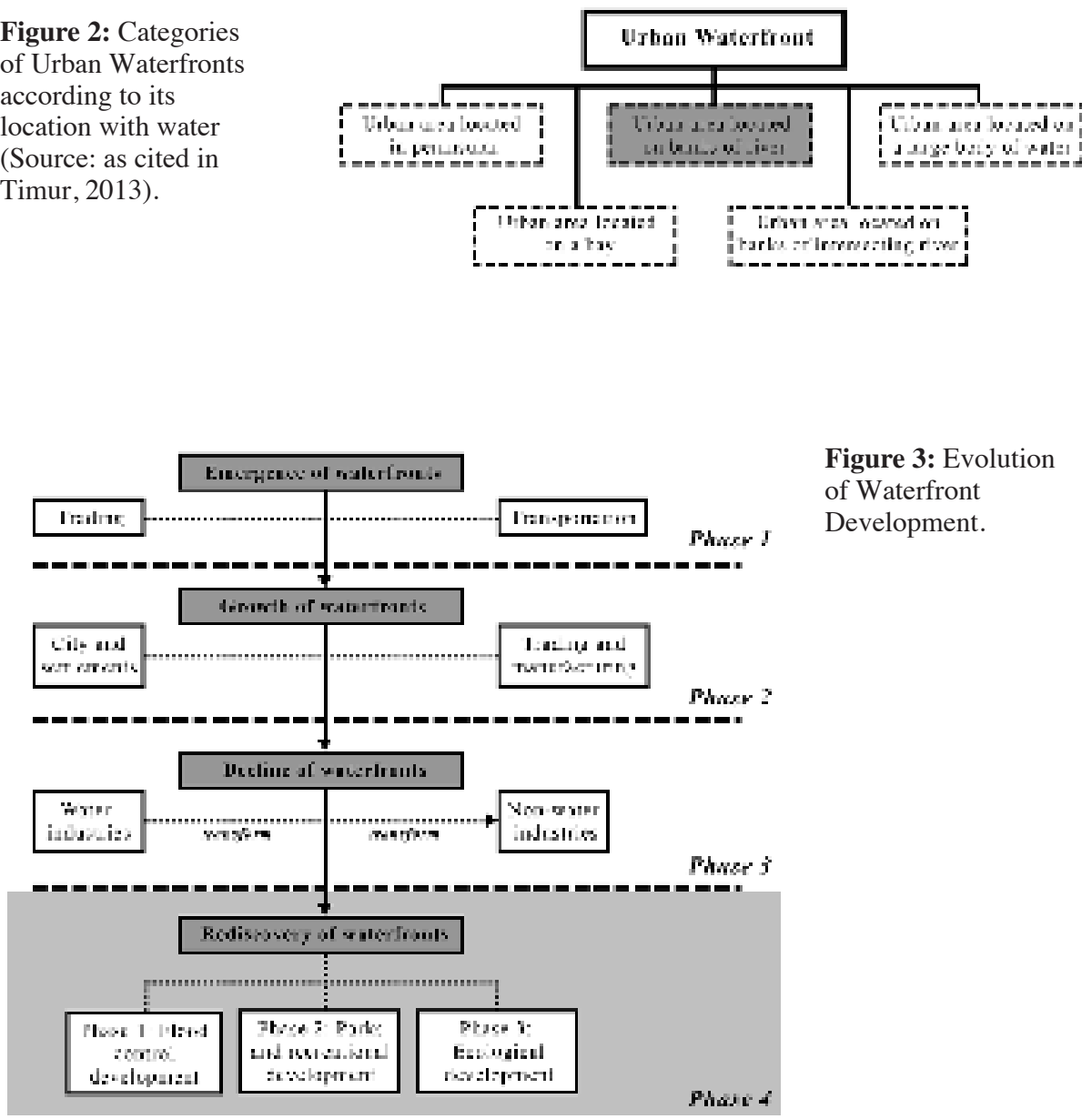

Figure 3: Evolution

of Waterfront

Development. 
Redzuan, $\mathrm{N}$ Abdul Latip, NS

to prevent natural catastrophes such as floods and arrest the worsening of pollution. These actions have led to the third phase, where the waterfront development focuses on ecological development along the riverbank areas. Acknowledging the mistakes and its adverse effects towards the environment, many developed countries such as the U.S.A., U.K., Japan, China and, many more have started to ecologically redevelop the riverfront in order to ensure that the rivers are restored to their natural condition $[15,24]$.

As mentioned above, it is important to know that this research only focused on urban areas located on banks of river. Md. Yassin et al. (2012) stated that developments along the riverbank in Malaysia are solely for recreation, residential and mix-use development [13]. Every redevelopment must be themed according to the history of the place, culture, climate, layout and design land use of development, with accessibility, pedestrian access and aesthetical value becoming the main attraction. Straightening and channelization of riverbank are the only water edge treatments applied, as these are the fastest solutions to prevent excessive water flow during high flow. It can be seen that none of the riverfront redevelopment designs highlight the integration of ecological design principles into the riverfront design. Hence, this research aimed to redefine the principles of ecological riverfront design. The objectives of the research comprise identifying the natural characteristics of riverbanks for a better understanding of their role in relation to ecological riverfront design, examining the current riverfront redevelopment and, lastly, generating the principles of ecological riverfront design.

\section{LITERATURE REVIEW}

The Literature Review will cover studies on natural riverbanks, including its characteristics, patterns and orders, and current development of riverfronts. These topics are found to be related to each other as the natural riverbank formed and shaped due to its characteristics, depending on the stream orders - where it is located. Besides, the natural riverbank is the best reference to guide and redevelop the current riverfront in developed urban areas. Thus, it is important to understand what lies in the river and its surroundings.

\subsection{Understanding of Natural Riverbank Characteristics in Ecological Riverfront Design}

\subsubsection{Natural Riverbank System}

To identify the characteristics of the natural riverbank system, Cengiz (2013) in his research has highlighted the natural riverbank system that consist of 
the flood plain, watershed, natural resources and natural communities [3]. The flood plain, as stated here, is a part of the river corridor, which represents the areas bordering rivers and streams, serving the most important role in the riverbank system, especially during high floods. Currently, the floodplain area (Fig. 4) and (Fig. 5) is where many urban centres are developed. This is the area that is always affected by floods.

Meanwhile, the watershed is a larger sized area drained by a river and its tributaries, where different watersheds are separated with ridges or divides. Natural resources and communities, on the other hand, include the habitat that contributes in shaping the riverbank system such as the river, native vegetation, soil and terrestrial and aquatic species.
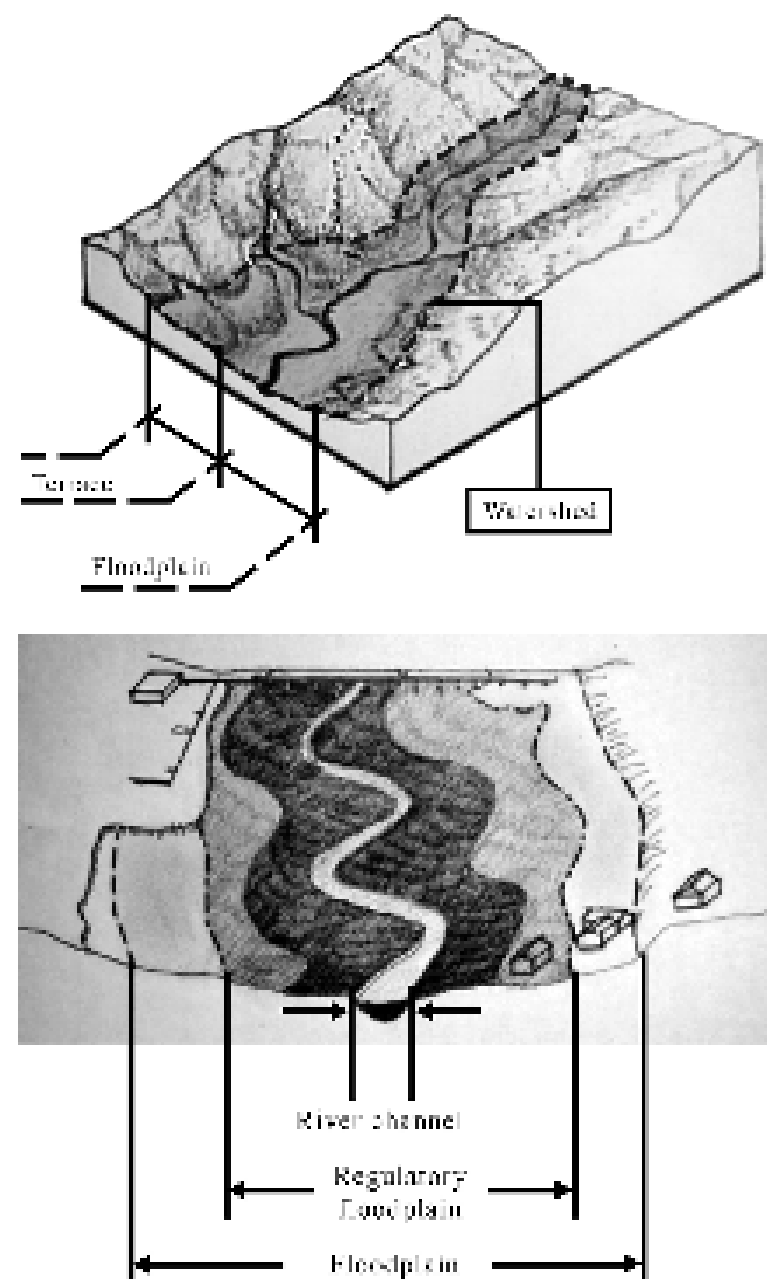

Figure 4: Major

Physiographic Elements of a

Typical Floodplain (Redrawn from Cengiz, 2013).
Figure 5: Presentation of the Regulator Floodway and Floodway Fringe by U.S. National Flood Insurance Program.(Redrawn from Cengiz, 2013).
Principles of

Ecological Riverfront Design

Redefined 
Redzuan, N

Abdul Latip, NS

\subsubsection{Natural communities}

Characteristics of natural riverbank could not be defined without the communities that lie within the riverbank area. There are many different ecological communities of living and non-living components that exist along the riverbank and its adjacent landforms. Natural riverbank communities consist of the hydrology, landform, soil, aquatic species and other living habitat such as vegetation and animals. These surround and lie within the river basin, serving different functions that benefit the riverbank system. For instance, vegetation that grows within the riverbank areas depends on the type of soil and water flow in a particular area. This indicates that there can be many different ecological communities that exist along the riverbank. The types of landform and channel slopes contribute to the formation of other riverbank features such as pools, riffles, rapids, cascades and steps. In fact, as the stream flow varies, discharge of sediment loads and types of soil play a decisive role in controlling the species of plants that grow surrounding the river [11,22].

The diversified riverbank characteristics form as natural communities that help each other to maintain the properties of the environment and balance them in a mutual cycle. Thus, understanding the natural riverbank characteristics is crucial in order to identify the ecological patterns based on the natural riverbank system. However, the characteristics of natural riverbank are not only focused on what lies on the riverbank area as the changes that happen in natural river patterns are closely linked with the riverbank. Thus, it is also important to acknowledge the changes of natural river patterns in order to integrate the ecological principles into the riverfront development.

\subsection{Changes of Natural River Patterns}

Based on the previous section, it can be stated that natural riverbank system is unpredictable as it is constantly changing [3]. The changes that occur in natural river patterns are not exempt from experiencing the same process.

According to Leopold \& Wolman (2004), the types of river channel patterns, as illustrated in Fig. 6, consist of the Braided, the Meandering and the Straight. The channel patterns are intergraded and linked to form a continuum of natural stream channels, where Braided may be Meandering and Meandering tributaries may join the Braided master stream [11]. The evolution of the river channel occurs mainly due to the change of stream flow magnitude, sediment regime, direct disturbances and vegetation changes [29].

Braided river can be recognized through the existence of alluvial islands, where the river flows in two or more channels. This pattern is formed as a result of sediment loads carried during the water flow; containing coarse particles consist of 


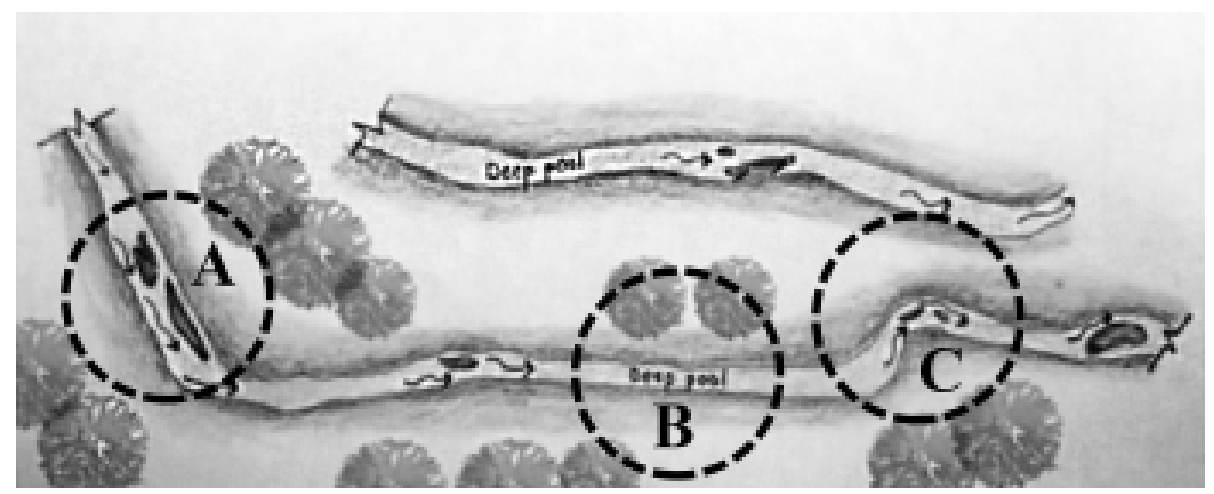

Principles of

Ecological

Riverfront Design

Redefined

Figure 6: The reach of the Middle River near Staunton, Va, showing how the Meander, Braided and Straight patterns, connected together, form a river channel -- (A) Braided pattern (B) Straight pattern (C) Meander pattern. (Source: Leopold and Wolman, 2004).

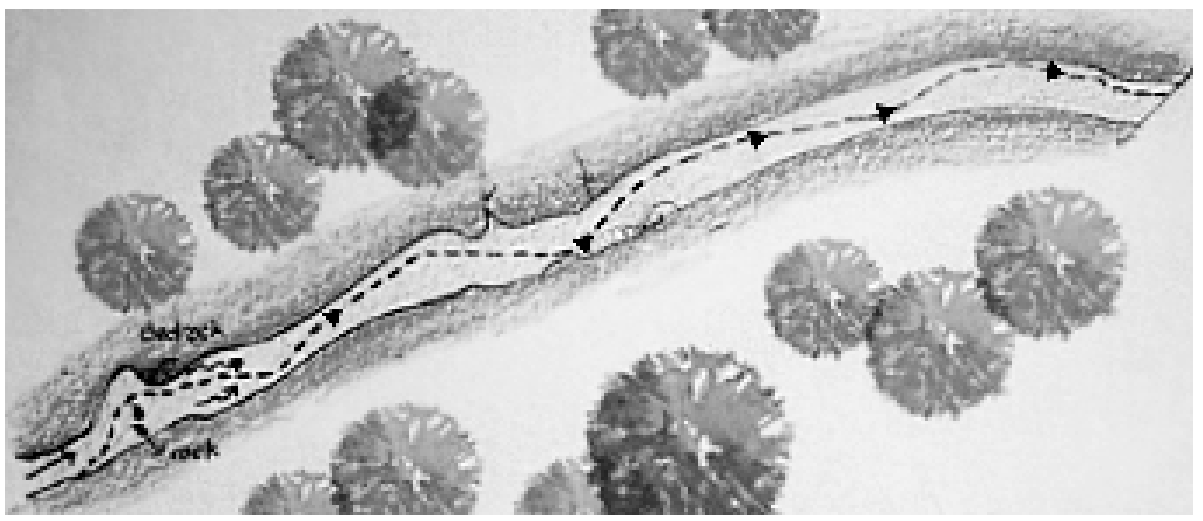

Figure 7: The Valley Creek at Sugar Ridge Farm near Downingtown, Pa. The flow of water is in a sinuous path within straight channel river. (Source: Leopold and Wolman, 2004).

gravel bars that could not be transported through the river channel, accumulating at the center of the channel and trapped finer particles, which contribute to the development of alluvial islands. However, the deflection of water flow against the riverbanks caused by the continuous development of bar island leads to the erosion of the riverbanks and channels widening in order to stabilize themselves. Straight channels, on the other hand, are very rare among the natural rivers.

Nevertheless, the flow of water within a straight channel does not seem to follow the channel. Leopold \& Wolman (2004) indicate that the flow is in a sinuous path even within the confine of their straight banks (Fig. 7). This kind of flow pattern exhibits the changes of river channels, to a meander and braided, turning back to the straight (Fig. 6). The channels can change within a short time taking one or two years to form another pattern [11]. 
Redzuan, $\mathrm{N}$ Abdul Latip, NS

In conclusion, the river can be defined as a complex natural structure that could adapt and respond to various conditions. The composition of the riverbank system portrays various unique characteristics that lead to different kind of pattern changes. It can be said that different parts of the river could influence the natural river patterns. Thus, the next section will briefly introduce the parts of a river that exist in relation to ecological riverfront design.

\subsection{Understanding the Stream Orders}

In developing ecological riverfront design principles, one does not simply ignore the original state of river and its morphology. According to (Endreny, 2003), rivers were classified based on the Stream Order. The Stream Order is a method for classifying the relative location of reach or tributaries within the larger river system. The system showed here is the method for Stream Order, where Order 1 represents the headwater. The confluence of two first order streams lead the formation of Order 2 stream, which is slightly larger that Order 1 stream. Next, the confluence of two 2nd-order streams results in a formation of Order 3 , representing the midstream section of the river system and so on, as illustrated in the Fig. 8 [7].

Based on Fig. 8, it can be said that a river can be divided into three parts, known as Upstream, Midstream and Downstream. Each part represents different settings, where the Upstream symbolizes the natural characteristics of the riverbank system that are still preserved, while Midstream and Downstream, on the other hand, present the images of rivers that flow into the settlements and big cities. However, it is important to note that Midstream and Downstream are parts of rivers that currently experience rapid urbanization compared to the Upstream. This indicates that different parts of river may require different approaches for integration into the principles of ecological riverfront design.

\subsection{Riverfront Development in the Present}

The inclusion of human interference in the natural activities through rapid development has contributed to the massive transformation of riverbanks, as most of it no longer resembles its original state. In fact, riverbank development in urban areas has made the change processes even faster and more drastic. Referring to the historical milestone of waterfront development from Fig. 1, the current redevelopment of riverfront is in the Phase 4, where the main purposes of development are for flood control, creation of recreational parks and for ecological development [18]. This is because not all riverbank areas can be reorganized due to the highly developed urban areas [10]. 


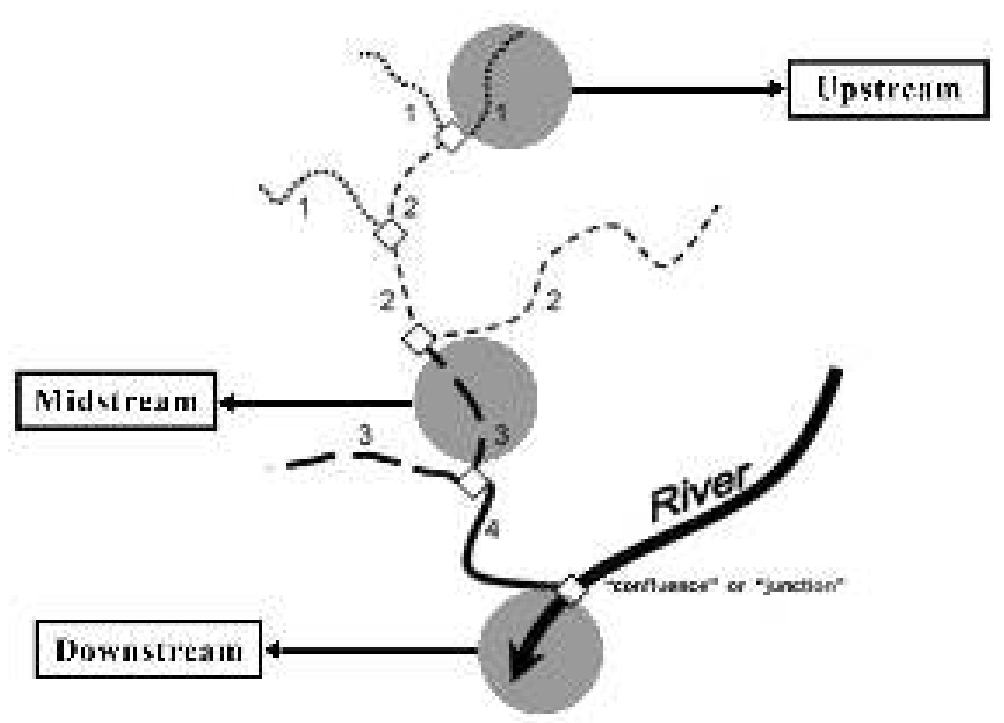

Principles of

Ecological Riverfront Design

Redefined

Figure 8: Classification of stream orders. (Source: As cited by Endreny, 2003).

The ecological improvement of riverfronts can be divided into two types, that is, River Restoration and River Rehabilitation. Restoration has been referred to projects that have a high potential of meeting the natural condition of the river, while River Rehabilitation was specific to the river that had been urbanized to the extent that there was limited land available to achieve ecological improvements [1]. This indicates that the implementation of River Restoration and Rehabilitation depends on the current condition of the riverfront. Riverfront development does not necessarily aim for restoring the natural setting of the riverbank. Improving its ecological setting would be sufficient if processes for full restoration cannot be conducted.

\section{METHODOLOGY}

A Qualitative Method was employed in this research, using the technique of case studies and content analysis of various reports from other researchers and selected countries, including those on ecological riverfront design and ecological riverfront design guidelines that were used to redefine the principles for ecological riverfront design. In this research, a total of 24 case studies from Asian, European, Middle East and Western countries were selected. In addition, the selection of journals and design guidelines depended on the urban context and types of riverfront development proposed. 
Redzuan, $\mathrm{N}$ Abdul Latip, NS

Examples from Asian countries included nine from China, one from India and, two from Japan, while those from European countries included two from Germany and one from Italy. Only one example from Iran represented the Middle-East. Other Western countries were represented by two examples from the United Kingdom and six from the United States. These are the countries that have outlined the ecological riverfront design guidelines and currently redeveloping their riverfronts based such principles. Journals and reports that are mostly stated are from China, Japan, U.S., U.K. and Germany as they are extensively redeveloping rivers based on the ecological aspects. On the contrary, most of the rivers development in India are not aimed for ecological improvements, but more towards improving the water quality and reducing pollution [6]. This explains why the study on ecological riverfront design in India is limited.

The principles of ecological riverfront design from various countries were analyzed and refined. Next, the principles were defined in stages and classified according to four main principles namely, (1) General Principles, (2) Planning Principles, (3) Design Principles and, (4) Implementation Principles. The four main principles were then further analyzed and categorized according to two types of riverfront redevelopment, i.e., Restoration and Rehabilitation of the riverfront.

Next, all the principles were finalized in accordance with types of River Orders -- Upstream, Midstream and Downstream. Not all principles could be applied on the same area since each part of the river possessed different habitat and riparian conditions that require a different approach.

\section{DISCUSSION}

Realizing the importance of ecological aspect, many developed countries all around the world have started to encourage and pull out their effort in developing the ecological riverfront. They have started to give back the land to the river.

According to Otto et al. (2004), the General Principles are important in order to set the stage for planning success [17]. This is the stage where the first idea and starting point of river ecological improvements take place. Generally, many studies claimed that principles of ecological riverfront design should be prioritized to conserve the riverbank areas that still possessed its natural characteristics $[4,28]$. This is shown through the case studies from China, Japan, India, Iran, U.S.A., U.K. and Germany, where conservation of critical and sensitive riparian areas is highly recommended. Thorough study on river components and its characteristics is also found to be one of the most important 
things that need to be taken into account in conducting any river restoration projects $[27,8]$.

Planning Principles, on the other hand, focus on the land area where there is a river flowing. This is the phase where the selection of sites is crucial, especially in urban areas, where the land available for ecological improvements is very limited [1]. As most of the urban development has taken place within the floodplain area, planning concerns such as 100-year floodplain and 'bluefield' development should not be left out to prevent the site being vulnerable to flooding [28]. The proposed ecological improvements also need to be adjustable to any events, besides considering the existing habitats and riverbank structures while planning towards the ecological riverfront design [21].

The next stage of Design Principles suggests how to implement the General and Planning Principles, including the riverbank restoration techniques and innovative programs to interpret the natural resources and cultural history of river. Based on the study, the connectivity of rivers and its riparian areas was found to be the most important element that needs to be addressed [24]. Using native vegetation as landscape to connect the isolated patches along the riverbank [5] and construction of water networks to connect the rivers and other water bodies are some of the alternatives [20] to enhance the natural features of riverbank. However, this sensitive natural area is prone to be colonized by invasive species. Thus, a buffer to protect the sensitive natural areas along the riverbank will really come in handy [9]. On a side note, the keys to the success ecological improvements of riverfront design are through the removal all the manmade structures that block the process and recreating the natural setting of the riverbank. Yet, these methods are not applicable to all sites due to the different site constraints [18]. To sum up, it can be stated that integration of a multi-layered edge design that combines the manmade landscape, riverbank stabilization techniques and natural features is greatly encouraged to create a better result.

Last but not least, Implementation is the stage where physical realization of design principles and implementation techniques are carried out [26]. For instance, implementation of bio-engineering banks is heavily discussed in case studies in China, Germany, Iran and U.S.A. Bio-engineering banks, as stated here, are proposed to soften the engineered banks by replacing the structured engineered banks with natural materials that allow vegetation to colonize $[4,9]$. This is followed by the implementation of natural storm water management that acts as a temporary reservoir, especially in urban areas that are highly exposed to flooding. This technique is widely applied in China, U.S.A. and U.K. Bio-retention ponds, green roofs, storm water planters, rain gardens and parks are some of the implementation techniques used to keep rain water before it flows back to the river
Principles of

Ecological

Riverfront Design

Redefined 
Redzuan, $\mathrm{N}$ Abdul Latip, NS

[15]. Other implementation techniques included are the removal of upper concrete wall of channelized riverbanks [25], implementation of sustainable practices with low environmental impact [2] and, using natural re-colonization sources provided by tributaries [19]. Hence, it can be stated that the implementations are meant to allow the vegetation to colonize along the riverbank. However, this is not surprising as the enhancement of riparian vegetation along the riverbank for improving ecological riverfront design is widely stated by many researchers.

\section{FINDINGS}

Based on the journals and reports obtained, it can be stated that all the guidelines and principles outlined above can be used and applied within the Malaysian context as well since the current urbanization patterns show no significance difference from other countries.

There are six major findings derived from this research:

(i) None of the guidelines and principles is specifically designed according to the stream orders. The different features of upstream, midstream and downstream stream orders require different approaches that should be implemented accordingly.

(ii) It can be agreed that identifying the most suitable site is the crucial part before conducting any riverfront redevelopment. This is the phase where all the important and sensitive areas are identified and conserved.

(iii) Integration of natural features and man-made structures can be cited as the best alternative to achieve ecological riverfront design for developed urban areas. This can be achieved through the combination of manmade landscape, riverbank stabilization technique and natural features, depending on the site requirements.

(iv) For developed urban areas where it is impossible to redevelop the riverfront, natural storm water management was found to be the best alternative to counter natural events such as flood. Some of the implementation methods, which act as temporary reservoirs, preventing runoff before it is released back to the river, include bio-retention ponds, rain gardens and green roofs.

(v) The method used to categorize the principles according to stages, i.e., general, planning, design and implementation principles, could be used to measure the current stages of riverfront development in Malaysia. Not all guidelines and principles are suitable for all stream orders,

(vi) The principles of ecological riverfront design based on the types of ecological improvements and stream orders outlined in this research could contribute in identifying the most suitable ecological riverfront design approaches in each stream orders. 
Table 1: The Principles of Ecological Riverfront Design: Restoration and Rehabilitation Project for the Upstream

\begin{tabular}{|c|c|c|c|}
\hline \multirow{3}{*}{$\begin{array}{l}\text { Pairs } \\
\text { "II } \\
\text { Tiver }\end{array}$} & \multirow{3}{*}{ Tyjes of $P_{1}$ iskijiles } & TERSTMExTIS & TEKH.SRII.TT:STIDS \\
\hline & & 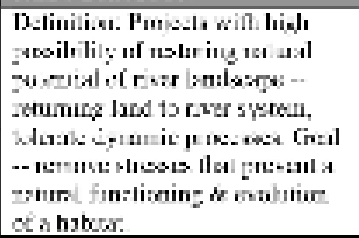 & 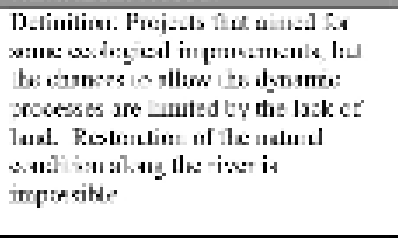 \\
\hline & & 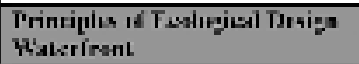 & 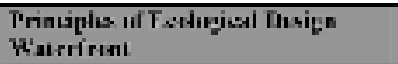 \\
\hline 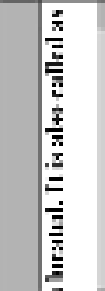 & 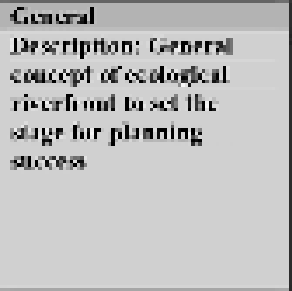 & 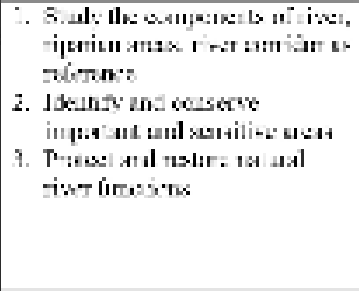 & 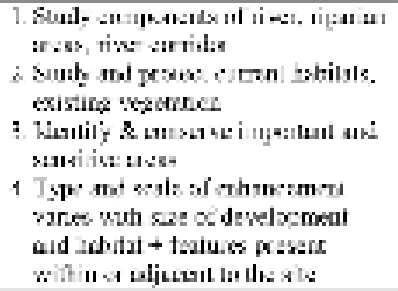 \\
\hline. \pm & Ylinaing & .. Censuder the thersuecisa:s, & 1. Henty bes sub locsilisa \\
\hline 恶 & 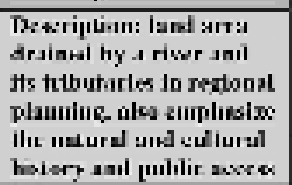 & 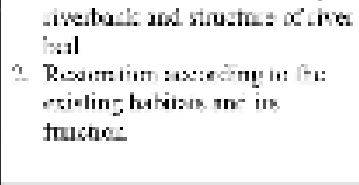 & 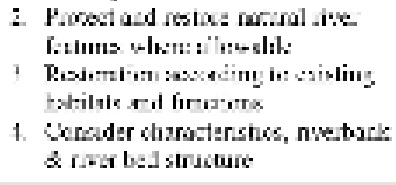 \\
\hline 器竞 & Despiu & 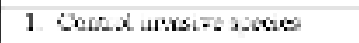 & 2. Coutrel inzastespeciss \\
\hline$\frac{-1}{3}$ & 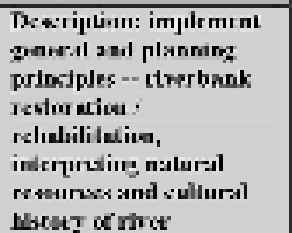 & & \\
\hline 的 & Tnpilt:me:na at iin & 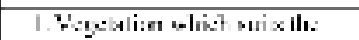 & 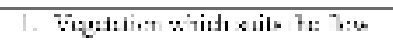 \\
\hline 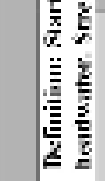 & 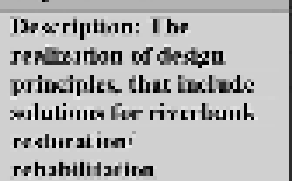 & 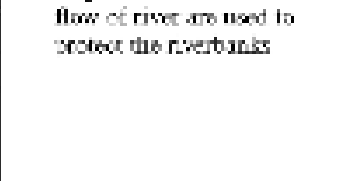 & 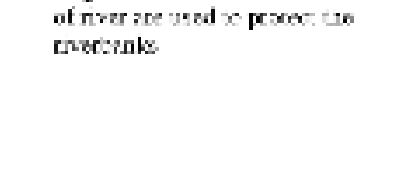 \\
\hline
\end{tabular}

The principles of ecological riverfront design in Malaysia are discussed based on the river restoration-rehabilitation according to the stream orders: the upstream, midstream and downstream as explained in Table 1, Table 2 and Table 3.

\section{CONCLUSION}

This research redefined the principles of ecological riverfront design. Based on the findings, it can be concluded that, although not all rivers can be redeveloped,
Principles of

Ecological

Riverfront Design

Redefined 
Table 2: The Principles of Ecological Riverfront Design: Restoration and Rehabilitation Project for the Midstream.

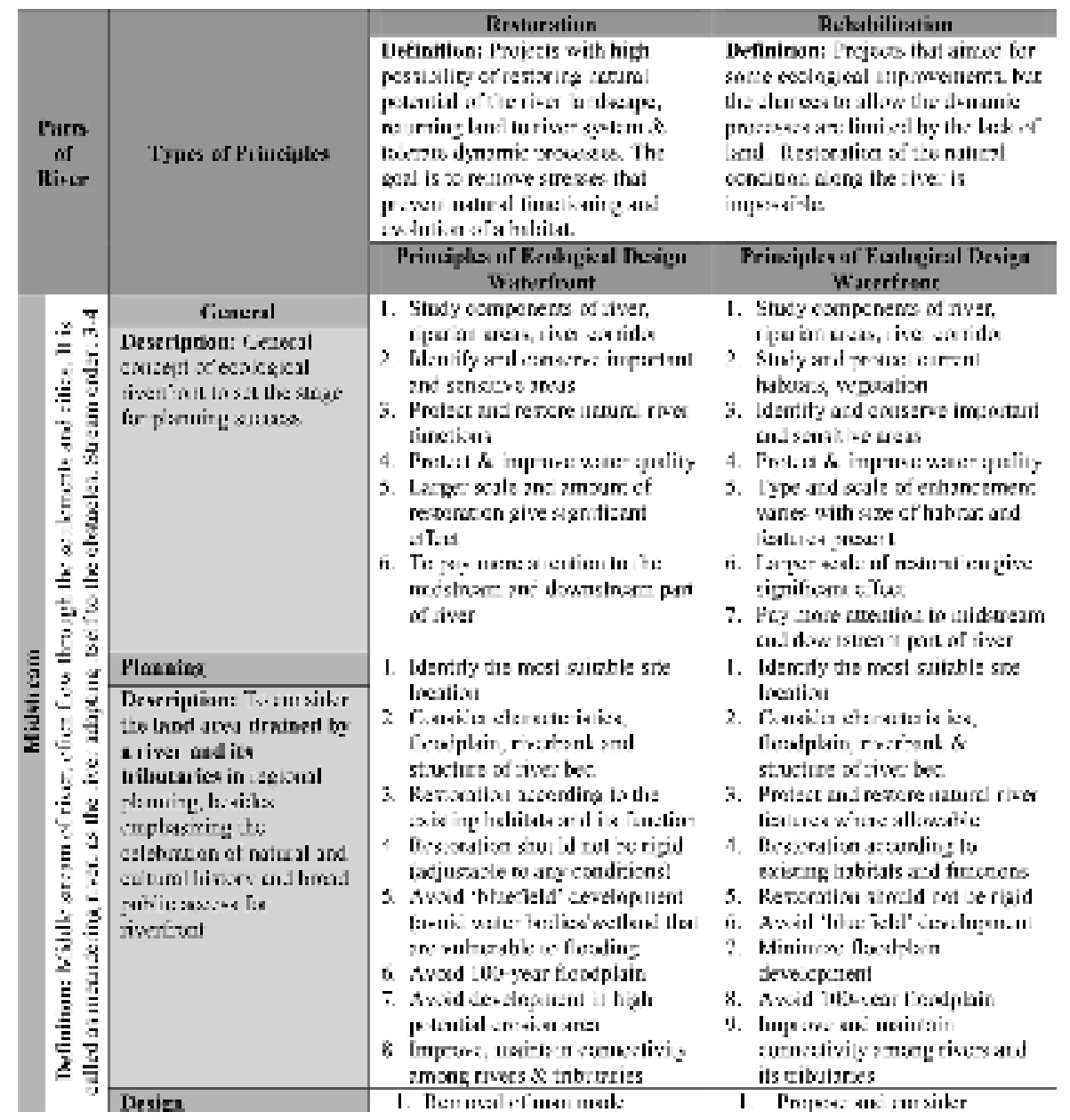

other possible areas that still have potential to be improved can be taken into account. Various guidelines analyzed showed that there are options to redevelop riverfronts through some ecological improvements. To secure the riverfront growth, it is important for riverfront to be restored and rehabilitated based on the suitable approaches according to the stream orders that will enhance its features. The restoration and rehabilitation could not have been done without going through the stages of principles: (i) General, (ii) Planning, (iii) Design 
Table 3: The Principles of Ecological Riverfront Design: Restoration and Rehabilitation Project for the Downstream.

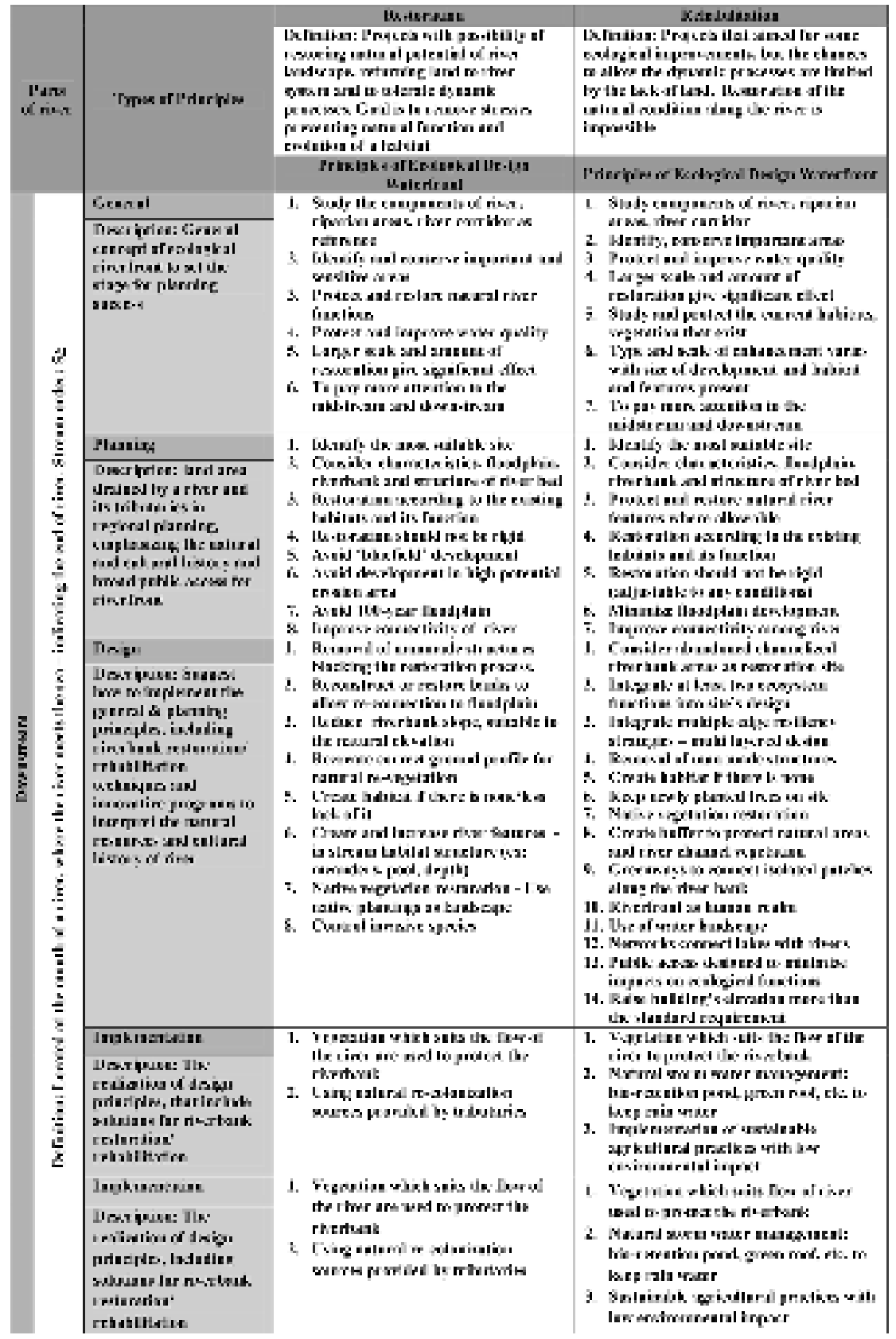


and (iv) Implementation. Every ecological riverfront design development need to undergo through each of the above stages in order to identify and implement the most appropriate solution for riverfront restoration and rehabilitation. Whether upstream, midstream or downstream, all principles outlined above are, without doubt, aimed at reconnecting the riverfront with the public while allowing the nature do its work. These principles could encourage all related professional bodies, including architects, planners, engineers and developers, to reconsider the ecological aspect of the riverfront while planning and creating urban spaces along the riverbank. Implementing the principles of ecological riverfront design not only promotes urban sustainability in developed urban areas but leads to a comfortable and healthy lifestyle as well.

\section{ACKNOWLEDGEMENTS}

This research is supported and funded by MOHE - Ministry of Higher Education under RAGS (Research Grant Scheme) and IIUM (International Islamic University Malaysia)

\section{REFERENCES}

[1] BINDER, W., GÖTTLE, A., and SHUHUAI, D. (2015) Ecological restoration of small water courses, experiences from Germany and from projects in Beijing. International Soil and Water Conservation Research, 3 (2), 141-153. Available from: http://doi.org/10.1016/j.iswcr.2015.04.004.

[2] BRAIONI, M.G., VILLANI, M. C., BRAIONI, A., and SALMOIRAGHI, G. (2012) Integrating Habitat Conservation with Amenity and Recreational Uses Along an Urban Stretch of the Adige River, Northern Italy. In: BOON, P. J. and RAVEN, P. J. (eds.), River Conservation and Management. 1st ed. West Sussex: John Wiley and Sons, 345-355.

[3] CENGIZ, B. (2013) Urban River Landscapes. In: OZYAVUZ, M. (ed.), Advances in Landscape Architecture. 1st ed. Rijeka: InTech, 551-586.

[4] CHEN, W. (2014). River Restoration in Asia and the Asia Restoration Network. In: Proceedings of the 6th Edition of European River Restoration Conference, Vienna, 27-29 October 2014. Available from: http://www. ecrr.org/Portals/27/Events/ERRC2014/Presentations/28\%20october\%20 2014/Side_events/River\%20Restoration\%20in\%20Asia\%20and\%20 ARRN_1.pdf [Accessed: ??] 
[5] CRIMMENS, T., and MARIT, L. (2006) Ecological Restoration and Management Plan. [Online] Bronx River Alliance, New York. Available from: http://www.bronxriver.org/plans [Accessed: ??]

[6] DANDEKAR, P., and THAKKAR, H. (2012) Ecological Management of Rivers in India : A Long Road Ahead. [PowerPoint slides]. Available from http://sandrp.in/rivers/Ecological_Management_of_Rivers_in_ India_Jan_2012.PDF [Accessed: ??]

[7] ENDRENY, T. A. (2003) Fluvial Geomorphology Module. UCAR COMET Program and NOAA River Forecast Center.[Online]. Available from http://www.fgmorph.com/ [Accessed: ??]

[8] HONG, B., LIU, S., and LI, S. H. (2011). Ecological Landscape Planning and Design of An Urban Landscape Fringe Area: A Case Study of Yang'an District of Jiande City. Procedia Engineering, 21, pp. 414-420. Available from:

http://doi.org/10.1016/j.proeng.2011.11.2033.

[9] KALANTARI, F., TAHIR, O. M., GOLKAR, N., and KALANTARI, S. (2015). Restoration of Tajan River Through Ecological Design Approach. Alam Cipta, 8(1), 52-59. Available from: http://www.academia. edu/26580637/Restoration_Of_Tajan_River_Through_Ecological_ Design_Approach.

[10] LEEDS CITY COUNCIL (2006) Biodiversity and Waterfront Development. Leeds:LCC. Available from http://www.leeds.gov.uk/docs/Biodiversity and Waterfront Development - Supplementary Planning Document.pdf [Accessed: ??]

[11] LEOPOLD, L. B., and WOLMAN, G. (2004) River Channel Patterns Braided, Meandering and Straight. In: SLAYMAKER, O. (Ed.), Fluvial Geomorphology. 1st ed. New York: Routledge, 39-85.

[12] MD. YASSIN, A., BOND, S., and MCDONAGH, J. (2011) Developing Guidelines for Riverfront Developments for Malaysia. Pacific Rim Property Research Journal, 17(4), 511-530. Available from: http://doi.org/10.1080/14445921.2011.11104340.

[13] MD. YASSIN, A., BOND, S., and MCDONAGH, J. (2012) Principles For Sustainable Riverfront Development For Malaysia Keywords : Waterfront, Development guidelines Waterfront Riverfront Riverfront. Journal of Techno-Social, 4 (1). Available from

http://eprints.uthm.edu.my/2855/

[14] MD. YASSIN, A., EVES, C., and MCDONAGH, J. (2010) An Evolution of Waterfront Development in Malaysia. In: Proceedings of the 16th 
Redzuan, N Abdul Latip, NS
Annual Conference of the Pacific Rim Real Estate Society, Wellington, 2427 January 2010. Available from http://researcharchive.lincoln.ac.nz/handle/10182/3215 [Accessed: ??]

[15] MILLER, D. (2013) The Hudson River Estuary Habitat Restoration Plan. New York State Department of Environmental Conservation, Hudson River Estuary Program. Available from http://www.dec.ny.gov/lands/5082.html [Accessed: ??]

[16] ORMEROD, S. J., and DURANCE, I. (2012) Understanding and Managing Climate Change Effects on River Ecosystems. In: BOON, P. J. and RAVEN, P. J. (eds.) River Conservation and Management. 1st ed. West Sussex: John Wiley and Sons, pp. 107-119..

[17] OTTO, B., MCCORMICK, K., and LECCESE, M. (2004) Ecological Riverfront Design: Restoring Rivers, Connecting Communities. Chicago: American Planning Association.

[18]RONG, L. (2011) Ecological Reflection on the Current Development of Mainland China's Urban Waterfront : A Case of Wuhan. In: Proceedings of the 47th ISOCARP Congress, Wuhan, 24-28 October 2011. 1-8. Available from http://www.isocarp.net/Data/case_studies/2016.pdf [Accessed: ??]

[19] SEMRAU, M., and HURCK, R. (2012). Multi-Purpose, Interlinked and Without Barriers: The Emscher River Ecological Concept. In: BOON, P. J. \& RAVEN, P. J. (eds.), River Conservation and Management. 1st ed, West Sussex: John Wiley and Sons, 243-247.

[20] SHANNON, K., and YIYONG, C. (2013) (Recovering) China's Urban Rivers As Public Space. Footprint, 7(12), 27-44.

[21] SHISLER, J. K., IANNUZZI, T. J., LUDWIG, D. F., and BLUESTEIN, P. J. (2008) Ecological Benchmarking in An Urbanized Estuarine River System. Ecological Restoration, 26 (3), 235-245. Available from http://doi.org/10.3368/er.26.3.235

[22] STROMBERG, J. C., LITE, S. J., and DIXON, M. D. (2010) Effects of Stream Flow Patterns on Riparian Vegetation of A Semiarid River: Implications for A Changing Climate. River Research and Applications, 26(7), 712-729. Available from http://doi.org/DOI: 10.1002/rra.1272

[23] TIMUR, U. P. (2013) Urban Waterfront Regenerations. In: ÖZYAVUZ, M. (ed.), Advances in Landscape Architecture. 1st ed. Rijeka: InTech, 169-206. http://doi.org/10.5772/55759

[24]TURENSCAPE (2007) Kunming Greenways. [Online]Available from http://old.turenscape.com/english/projects/project.php?id=4557 [Accessed: July 1, 2016] 
[25] TURENSCAPE (2007) Reshaping An Urban Water Front: The Yinzhou Central River Transformation. [Online]Available from http://old. turenscape.com/english/projects/project.php?id=454 [Accessed: July 1, 2016]

[26] URBEM, URBAN RIVER BASIN ENHANCEMENT METHODS (2004) Final Report on Existing Urban River Rehabilitation Schemes (Work Package 2). Available from http://www.urbem.net/WP2/WP2 case_studies.pdf [Accessed: ??]

[27] WASSERWIRTSCHAFTSAMT MUNCHEN (2011) A New Lease of Life for the Isar River [PowerPoint slides]. Available from http://climate-adapt. eea.europa.eu/metadata/case-studies/isar-plan-2013-water-managementplan-and-restoration-of-the-isar-river-munich-germany/11265923.pdf [Accessed: ??]

[28] WATERFRONT ALLIANCE (2015) Waterfront Edge Design Guidelines. [Online]. Available from waterfrontalliance.org/WEDG [Accessed: ??]

[29] ZHANG, Q., XU, C. Y., BECKER, S., \& JIANG, T. (2006) Sediment and runoff changes in the Yangtze River basin during past 50 years. Journal of Hydrology, 331, 511-523. Available from http://doi.org/10.1016/j. jhydrol.2006.05.036
Principles of

Ecological Riverfront Design Redefined

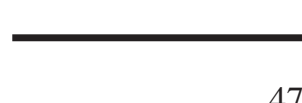

